\title{
Pengaruh Lama Perendaman terhadap Absorpsi Tetrasiklin pada Adsorben Limbah Sisik Ikan Gurami (Osphronemus Gouramy)
}

\author{
Sabrina M. Pratama*, Ghiza J.K. Barqly*, Retno Widyastuti*, Rizka N. Wardani**, Dear F. Sielma**, dan Al Munawir*** \\ *Fakultas Kedokteran Gigi, Universitas Jember, Jember, Jawa Timur, Indonesia \\ ${ }^{* *}$ Fakultas Kedokteran, Universitas Jember, Jember, Jawa Timur, Indonesia \\ ***Bagian Biomolekular, Fakultas Kedokteran, Universitas Jember, Indonesia \\ *JI Kalimantan 37, Jember, Indonesia; e-mail: sabrinampratama@yahoo.com
}

\begin{abstract}
ABSTRAK
Sisik ikan gurami (Osphronemus Gouramy) merupakan salah satu sumber alternatif kolagen alami yang bersifat biodegradable (mudah terurai) dan bio-compatible (kompatibel dengan jaringan sekitarnya) serta memiliki potensi sebagai bioadsorben. Sifat bioadsorben kolagen ini sudah dimanfaatkan sebagai media transport antibiotik tetrasiklin dalam bentuk chip, yang digunakan sebagai antibiotik lokal dalam perawatan periodontitis. Kekurangan chip ini yaitu harganya mahal serta harus diambil kembali dari jaringan gingiva karena tidak dapat diresorpsi tubuh. Potensi bioadsorben sisik dari ikan gurami diduga dapat dimanfaatkan sebagai media transport tetrasiklin dalam bidang biomedis. Penelitian ini bertujuan untuk mengetahui potensi absorbsi, kadar absorbsi serta pengaruh lama perendaman limbah sisik ikan gurami terhadap absorbsi antibiotik tetrasiklin. Sampel penelitian berupa sisik ikan gurami yang didapat dari rumah makan seafood di daerah Jember, Jawa Timur. Sebanyak $500 \mathrm{mg}$ sisik ikan direndam ke dalam $20 \mathrm{ml}$ larutan induk tetrasiklin hidroklorida dalam beaker glass. Larutan diambil sebanyak $200 \mu \mathrm{l}$ dengan mikropipet pada jam ke-0, jam ke-1, jam ke-2, jam ke-4, jam ke-12 dan jam ke-24 setelah perendaman. Absorbansi sisik ikan gurami terhadap tetrasiklin pada masing-masing interval waktu perendaman dibaca menggunakan spektrofotometer dengan panjang gelombang 450 $\mathrm{nm}$. Tahapan ini diulangi sebanyak lima kali. Hasilnya kadar tetrasiklin dalam larutan pada lama perendaman 1 jam menunjukkan kadar terendah yaitu 160,6 $\mu \mathrm{g} / \mu \mathrm{l}$. Dari pengamatan mikroskopis terlihat adanya ikatan antara tetrasiklin dan kolagen sisik ikan. Sisik ikan gurami dapat mengabsorbsi tetrasiklin dengan lama perendaman efektif yaitu 1 jam dengan mekanisme ikatan antara kolagen sisik ikan dengan kristal tetrasiklin.
\end{abstract}

Maj Ked Gi Ind. Desember 2015; 1(2): 161 - 166

Kata kunci: sisik ikan gurami, bioadsorben, absorpsi, tetrasiklin, spektrofotometer

\begin{abstract}
Influence of Immersion Length on Tetracycline Absorption on Gourami (Osphronemus Gouramy) Scales as Adsorbent. Gourami (Osphronemus Gouramy) scales are one of the natural sources of collagen. This fish scale's collagen has functional properties, such as bio-degradable (easily decomposed), bio-compatible (compatible with surrounding tissue), and potential as bio-adsorbent. The absorbent properties of collagen are currently used as a transport material in local drug delivery for periodontal disease treatment, which is known as tetracycline chip. However, this chip is made of synthetic collagen so it is not absorbable by the body's system. The price is also expensive. This study's aim is to prove the potency of Gourami scales as a source of collagen in medical treatment, especially as a transport material of tetracycline for periodontal disease treatment. The gourami scale was obtained from seafood restaurant in Jember, Jawa Timur. About $500 \mathrm{mg}$ of gourami scales was immersed into $20 \mathrm{ml}$ tetracycline solution in beaker glass. About $200 \mu \mathrm{l}$ solution from the beaker glass was taken with micropipette after 1-hour, 2-hour, 4-hour, 12hour and 24-hour after immersed. After that, the solution was collected into an eppendorf for each time. The absorbance was measured with spectrophotometer at $450 \mathrm{~nm}$ wave length. This procedure was repeated five times. The lowest absorbance occured at 1-hour time $(160,6 \mu \mathrm{g} / \mu \mathrm{l})$. The result from light and inverted microscope examination shows a bond between collagen from gourami scales with tetracycline. Gourami scale has the ability to absorb the highest rate of tetracycline at 1-hour immersed time by forming a bond between collagen and tetracycline.
\end{abstract}

Maj Ked Gi Ind. Desember 2015; 1(2): 161 - 166

Keywords: gourami scale, bioadsorbent, absorption, tetracycline, spectrophotometer

\section{PENDAHULUAN}

Ikan gurami (Osphronemus Gouramy) merupakan jenis ikan air tawar yang banyak dibudidayakan di kabupaten Jember, Jawa Timur. Ikan ini pada umumnya hanya dagingnya saja yang dimanfaatkan, sedangkan bagian sisiknya men- jadi limbah baik dalam skala industri besar maupun skala rumah tangga. Sisik ikan gurami ini sebenarnya dapat diolah dan dimanfaatkan karena mengandung bahan organik, salah satunya kolagen. Kadar kolagen yang terkandung dalam sisik ini cukup tinggi, yaitu sekitar $29,8-40,9 \%$, 
sehingga sisik ikan juga dikenal sebagai sumber alternatif kolagen. ${ }^{1,2}$ Sisik ikan gurami ini memiliki potensi sebagai bioadsorben (bahan penyerap alami) logam karena kandungan kolagen tersebut. ${ }^{3,4}$

Kolagen merupakan material bio-degradable dan bio-compatible yang dapat digunakan sebagai sistem transpor antimikroba. ${ }^{5,6}$ Keuntungan penggunaan kolagen adalah sifat kompatibel dengan jaringan sekitarnya, kadar antimikroba pada target infeksi yang lebih tinggi dari MIC (Minimum Inhibitory Concentration) dan potensinya sebagai antimikroba dapat dilepaskan secara bertahap dalam jangka waktu lama. ${ }^{7}$ Sifat-sifat kolagen tersebut dapat dimanfaatkan dalam bidang medis, contohnya dalam terapi penyakit periodontitis.

Dari hasil studi kesehatan rumah tangga (SKRT) tahun 2001, periodontitis merupakan penyakit infeksi rongga mulut dengan prevalensi tinggi di Indonesia. Penanganan periodontitis harus dilakukan dengan tepat dan sesuai indikasi untuk mengatasinya. Salah satu prosedur dalam perawatan periodontitis yang dikenal adalah kuretase, yaitu proses pembuangan jaringan granulasi dan epitel penghubungnya pada daerah kantung/poket periodontal yang terinfeksi. Jaringan granulasi tersebut mengandung koloni bakteri yang menghambat penyembuhan walaupun sudah dilakukan scaling dan root planning, sehingga diperlukan tambahan terapi antimikroba untuk mempercepat penyembuhan dan meningkatkan efektivitas perawatan periodontitis. ${ }^{8.9}$ Salah satu antimikroba yang sering digunakan dalam perawatan periodontitis adalah tetrasiklin. Tetrasiklin mampu berkonsentrasi dalam jaringan periodontal dan menghambat pertumbuhan bakteri Actinobacillus actino-mycetemcomitansyang merupakan penyebab periodontitis. ${ }^{10}$ Tetrasiklin sering diberikan secara lokal karena efektivitas konsentrasi lebih tinggi, dan mengurangi efek samping serta resiko terjadinya resistensi bakteri. ${ }^{11}$ Daerah poket periodontal yang sulit dijangkau merupakan kendala dalam pemberian tetrasiklin secara lokal. Untuk mengurangi kendala tersebut, dalam beberapa tahun terakhir, tetrasiklin dibuat dalam bentuk sediaan chip yang terbuat dari kolagen. ${ }^{12}$ Chip ini memiliki kekurangan, yaitu harganya yang cukup mahal dan sifatnya yang harus diambil kembali dari poket karena tidak dapat diresorpsi tubuh secara alami.
Berdasarkan uraian di atas, diketahui bahwa kandungan kolagen yang terdapat pada sisik ikan gurami cukup tinggi dan bersifat bio-degradable, bio-compatible, serta bio-adsorben. Oleh sebab itu, peneliti tertarik untuk mengetahui lebih jauh potensi limbah sisik ikan gurami dalam aplikasi biomedis dengan melakukan penelitian ini. Penelitian ini menggunakan sisik ikan gurami segar dengan bobot rerata $1,2 \mathrm{~kg}$ yang sejenis pada bagian badan ikan gurami karena permukaannya lebih luas dan bentuknya lebih simetris. Tujuan dari penelitian ini adalah untuk mengetahui potensi dan kadar absorbsi serta pengaruh lama perendaman limbah sisik ikan gurami terhadap absorpsi antibiotik tetrasiklin.

\section{METODE PENELITIAN}

Alat yang digunakan dalam penelitian adalah Freeze Dryer Zirbus Technology VaCoseries-02-10, mikropipet, pipet tip, eppendorf, labu erlenmeyer, gelas ukur, petri dish, orbital inkubator, neraca elektrik, kertas alumunium tin foil, vortex, sentrifuge, cuvet, spektrofotometer R-Biopharm WELL Reader, Mikroskop Olympus CX-371. Bahan yang digunakan dalam penelitian antara lain sisik ikan gurami pada bagian badan, antibiotik tetrasiklin, larutan standart (Tetracycline PA SigmaAldrich), aquades, larutan ethanol 95\% $1 \mathrm{~L}$.

Preparasi sisik ikan gurami dilakukan dengan mengeringkan sisik ikan gurami melalui proses freeze drying selama 21 jam. Alat yang digunakan adalah Freeze Dryer Zirbus Technology VaCo-series-02-10. Sebanyak $200 \mathrm{mg}$ tetrasiklin hidroklorida dilarutkan dengan $20 \mathrm{ml}$ ethanol $95 \%$ pada gelas ukur 50 $\mathrm{ml}$ hingga didapatkan larutan induk tetrasiklin hidroklorida. Larutan induk dihomogenkan menggunakan vortex dengan kecepatan $2400 \mathrm{rpm}$.

Sisik ikan gurami seberat $500 \mathrm{mg}$ direndam ke dalam $20 \mathrm{ml}$ larutan induk tetrasiklin hidroklorida. Larutan induk dan sisik ikan dimasukkan ke dalam orbital incubator dengan kecepatan 110 rpm selama 2 menit supaya tidak terjadi pengendapan tetrasiklin. $200 \mu \mathrm{l}$ larutan sisik ikan gurami dalam tetrasiklin hidroklorida diambil pada jam ke-0, jam ke-1, jam ke- 2, jam ke-4, jam ke-12 dan jam ke- 24 setelah perendaman. 
Absorbansisisikikanguramiterhadaptetrasiklin pada masing-masing interval waktu perendaman dibaca dengan menggunakan spektrofotometri dengan panjang gelombang $450 \mathrm{~nm}$. Kadar absorbsi sisik ikan gurami terhadap tetrasiklin dihitung berdasarkan pada persamaan linear yang didapat dari hasil kurva absorbansi larutan standart Tetracycline Pro Analisa. Pengamatan dengan menggunakan mikroskop Olympus CX-371 dan mikroskop inverted selanjutnya dilakukan untuk mengetahui perbedaan morfologi sisik ikan gurami sebelum dan sesudah dilakukan perendaman.

Sisik ikan gurami seberat $100 \mathrm{gr}$ sebagai sampel dihilangkan kalsiumnya dengan menggunakan asam asetat $99 \%$. Sisik direndam dalam larutan tetrasiklin selama 1 jam. Sampel sisik normal dan sampel sisik perlakuan yang telah dihilangkan kalsiumnya masing-masing dihidrasi menggunakan nitrogen cair. Perbedaan morfologi diamati dengan menggunakan mikroskop Olympus CX-371 perbesaran 1000x dan ikatan tetrasiklin dengan struktur kolagen diamati dengan mikroskop inverted.

\section{HASIL PENELITIAN}

Absorbansi sisikikan gurami terhadap tetrasiklin pada masing-masing interval waktu perendaman ditunjukkan pada Tabel 1 dan Gambar 1.
Dari tabel dan kurva di atas, didapatkan absorbansi tetrasiklin terendah terjadi pada lama perendaman 1 jam, dengan rerata absorbansi 0,2656 pada $\lambda 450 \mathrm{~nm}$. Kadar absorbsi sisik ikan gurami terhadap tetrasiklin dihitung berdasarkan pada persamaan yang didapat dari kurva linear absorbansi Tetrasiklin Pro Analisa (Sigma-Aldrich) pada Gambar 2.

Dari kurva di atas, didapatkan persamaan linear $y=0,001 x+0,105$ dengan $R^{2}=0,796(y=$ absorbansi dan $\mathrm{x}=$ kadar tetrasiklin dalam larutan). Kadar tetrasiklin dalam larutan ditunjukkan pada Tabel 2. Kadar terendah tetrasiklin dalam larutan terdapat pada lama perendaman 1 jam, yaitu 160,6 $\mu \mathrm{g} / \mu \mathrm{l}$. Hal ini menunjukkan bahwa tetrasiklin paling banyak terserap ke dalam sisik ikan dengan lama perendaman 1 jam sehingga kadarnya yang ada dalam larutan berada pada titik terendah.

Tabel 2. Kadar absorbsi sisik ikan gurami terhadap tetrasiklin dengan interval waktu 0 jam, 1 jam, 2 jam, 4 jam, 12 jam, 24 jam.

\begin{tabular}{cc}
\hline Lama Perendaman & $\begin{array}{c}\text { Kadar Tetrasiklin dalam } \\
\text { Larutan }\end{array}$ \\
\hline 0 jam & $236,4 \mu \mathrm{g} / \mu \mathrm{l}$ \\
1 jam & $160,6 \mu \mathrm{g} / \mu \mathrm{l}$ \\
2 jam & $210,4 \mu \mathrm{g} / \mu \mathrm{l}$ \\
4 jam & $203,4 \mu \mathrm{g} / \mu \mathrm{l}$ \\
$12 \mathrm{jam}$ & $194,8 \mu \mathrm{g} / \mu \mathrm{l}$ \\
24 jam & $188,6 \mu \mathrm{g} / \mu \mathrm{l}$ \\
\hline
\end{tabular}

Tabel 1. Absorbansi sisik ikan gurami terhadap tetrasiklin dengan interval waktu $0,1,2,4,12,24$ jam pada $\lambda 450 \mathrm{~nm}$

\begin{tabular}{ccccccc}
\hline \multirow{2}{*}{$\begin{array}{c}\text { Lama } \\
\text { Perendaman }\end{array}$} & \multicolumn{7}{c}{ Absorbansi pada $\mathbf{4 5 0} \mathbf{~ n m}$} & \multirow{2}{*}{ Rata-Rata } \\
\cline { 2 - 6 } & 1 & 2 & 3 & 4 & 5 & \\
\hline 0 jam & 0,422 & 0,304 & 0,254 & 0,36 & 0,367 & 0,3414 \\
\hline 1 jam & 0,201 & 0,164 & 0,296 & 0,352 & 0,315 & 0,2656 \\
\hline 2 jam & 0,169 & 0,162 & 0,326 & 0,385 & 0,535 & 0,3154 \\
\hline 4 jam & 0,144 & 0,152 & 0,324 & 0,38 & 0,542 & 0,3084 \\
\hline 12 jam & 0,139 & 0,136 & 0,321 & 0,416 & 0,487 & 0,2998 \\
\hline 24 jam & 0,422 & 0,304 & 0,254 & 0,36 & 0,367 & 0,2936 \\
\hline
\end{tabular}

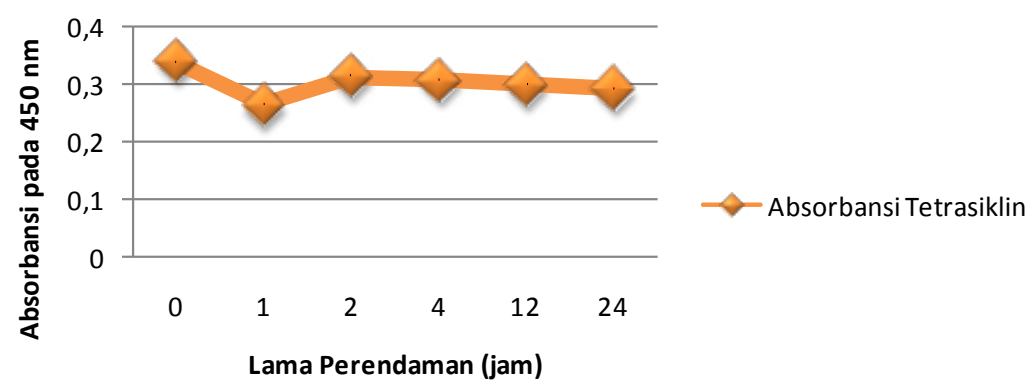

Gambar 1. Kurva absorbansi sisik ikan gurami terhadap tetrasiklin dengan interval waktu 0 jam, 1 jam, 2 jam, 4 jam, 12 jam, 24 jam 


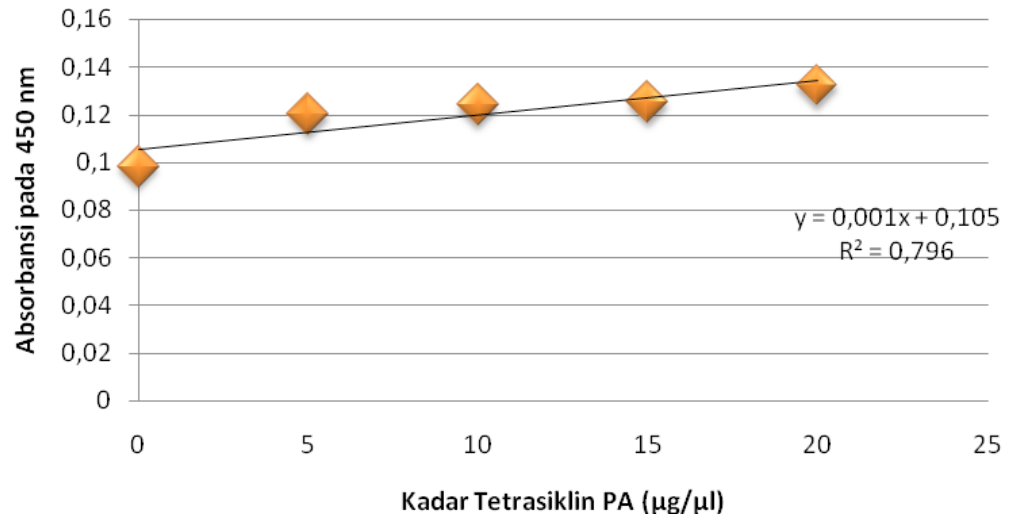

Gambar 2. Kurva linear absorbansi tetrasiklin pro analisa

Untuk membuktikan apakah tetrasiklin berikatan dengan struktur kolagen atau kalsium pada sisik, dilakukan pemeriksaan morfologi sisik. Morfologi sisik ikan gurami sebelum perlakuan dan sesudah perlakuan diamati dengan menggunakan mikroskop Olympus CX-371 dan mikroskop inverted Olympus IX51. Kalsium yang terdapat dalam sisik ikan gurami dihilangkan terlebih dahulu dengan menggunakan asam asetat $99 \%$ sehingga hanya tersisa komponen kolagen dalam sisik ikan gurami. Terdapat perbedaan morfologi yang ditunjukkan dengan adanya kristal-kristal tetrasiklin yang diduga melekat pada struktur kolagen pada sisik ikan yang telah dihilangkan kalsiumnya lalu direndam dengan larutan tetrasiklin hidroklorida selama satu jam. Hal tersebut ditunjukkan dalam Gambar 3 dan Gambar 4.

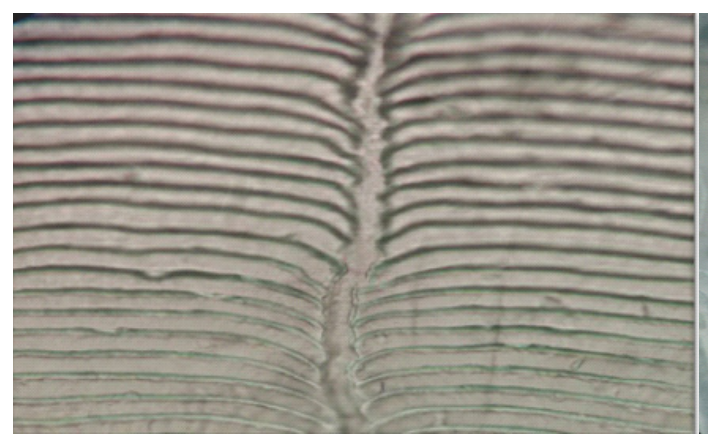

(A)

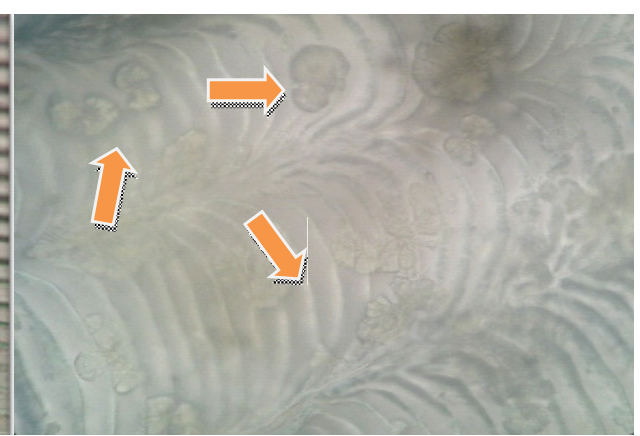

(B)

Gambar 3. Morfologi sisik ikan dilihat dengan Mikroskop Olympus CX-371 Perbesaran 1000x Gambar (A) Sisik ikan gurami sebelum direndam tetrasklin. Kristal tetrasiklin belum terlihat di antara serabut-serabut kolagen (B) Sisik ikan gurami sesudah direndam tetrasiklin. Kristal tetrasiklin terlihat di antara serabut kolagen (lihat tanda panah).

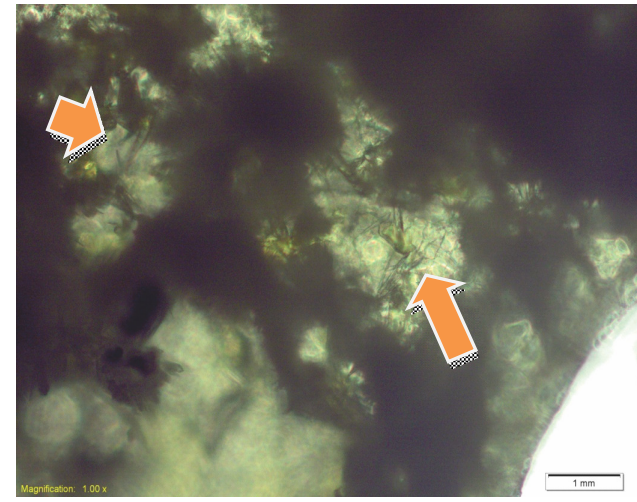

(A)

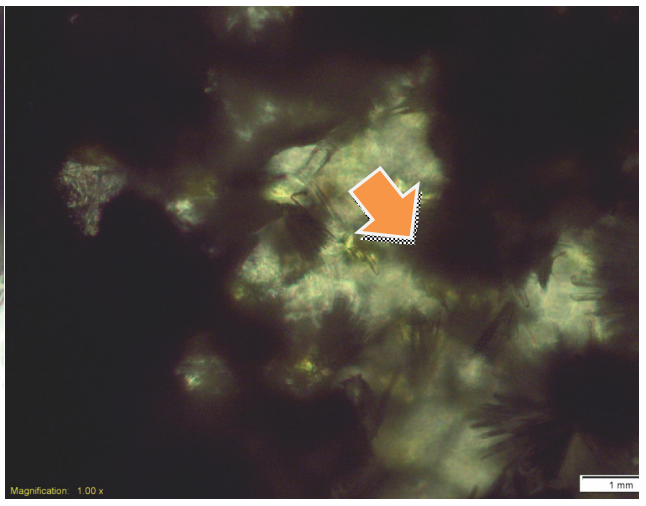

(B)

Gambar 4. Morfologi sisik ikan dilihat dengan Mikroskop Inverted Olympus IX51 Perbesaran 100x. Kedua gambar adalah sisik ikan yang kalsiumnya telah larut dan direndam larutan tetrasiklin. Yang ditunjuk tanda panah adalah kristal tetrasiklin yang berikatan dengan kolagen. 


\section{PEMBAHASAN}

Absorbansi adalah banyaknya cahaya atau energi yang diserap oleh partikel dalam larutan. Semakin banyak partikel yang ada dalam larutan, maka nilai absorbansinya akan semakin meningkat, begitu juga sebaliknya. Pada Gambar 1 absorbansi terendah terjadi pada lama perendaman 1 jam. Hal ini menunjukkan bahwa partikel tetrasiklin yang ada di dalam larutan berada dalam kadar terendah. Hasil ini dibuktikan dari persamaan yang didapatkan dari Gambar 2 yaitu $y=0,001 x+0,105$. Persamaan ini menunjukkan bahwa pada lama perendaman 1 jam, tetrasiklin berada pada kadar terendah, yaitu $160,6 \mu \mathrm{g} / \mu \mathrm{l}$. Hasil tersebut menunjukkan bahwa sisik ikan gurami berpotensi menjadi adsorben antibiotik tetrasiklin.

Dari Gambar 3 diketahui bahwa terdapat perbedaan antara sisik ikan yang tidak direndam larutan tetrasiklin dengan sisik yang direndam larutan tetrasiklin. Pada sisik yang direndam larutan tetrasiklin, terdapat bentukan kristal tetrasiklin. Tetrasiklin diduga berikatan dengan kolagen sehingga terjadi proses absorbsi. Pada Gambar 4 dapat dilihat bahwa kristal tetrasiklin berikatan dengan kolagen sisik ikan gurami.

Awalnya potensi adsorbansi sisik ikan diduga karena adanya ikatan yang terjadi antara ion kalsium dan tetrasiklin. Dalam bidang kedokteran gigi, tetrasiklin dapat menimbulkan diskolorisasi gigi akibat mengkonsumsi obat ini ketika hamil atau berusia muda. ${ }^{13}$ Diskolorisasi terjadi saat fase mineralisasi atau kalsifikasi gigi berlangsung. Tetrasiklin akan berdifusi ke jaringan pembentuk gigi dan berikatan secara ireversibel dengan ion kalsium (kalsium ortofosfat). Proses ini membentuk kompleks stabil dalam kristal hidroksiapatit yang terdapat dalam dentin dan enamel sehingga terjadi diskolorisasi. ${ }^{14,15}$ Pada penelitian ini kalsium sisik ikan telah dilarutkan sebelum dilakukan perendaman sehingga hal tersebut membuktikan bahwa tetrasiklin dapat berikatan secara langsung dengan kolagen sisik ikan.

Kandungan kolagen yang tinggi dalam sisik ikan membuat sisik ikan banyak diteliti untuk menjadi sumber alternatif kolagen. Kolagen merupakan biomaterial yang telah teruji fungsinya sebagai carrier material atau bahan pembawa substansi yang membantu pertumbuhan sel dalam tissue engineering. Hal ini juga didukung oleh sifat antigenitas yang rendah, biokompatibilitas yang baik, dan memicu promosi perlekatan dan proliferasi sel. ${ }^{16}$ Kolagen yang terdapat dalam sisik ikan tersusun atas beberapa gugus fungsional seperti fosfat, karboksil, amina dan amida. Gugus ini berperan dalam proses resorbsi ion logam berat. Gugus ini diduga berperan dalam ikatan tetrasiklin dengan sisik ikan gurami. Dalam bidang kedokteran gigi, kolagen telah banyak digunakan sebagai bahan yang memproduksi membran atau sebagai barrier untuk memicu regenerasi jaringan. ${ }^{9}$ Kolagen juga digunakan sebagai media administrasi obat secara lokal pada perawatan periodontitis, seperti Tetracycline chip. Dalam penelitian ini, sisik ikan terbukti dapat menjadi adsorben tetrasiklin. Perlu penelitian lanjutan untuk mengetahui kadar tetrasiklin yang dapat terabsorbsi hingga jenuh dan absorbsi sisik ikan terhadap tetrasiklin apakah hanya pada permukaan atau masuk hingga ke dalam struktur kolagen dengan menggunakan TEM (Transmission electron microscopy).

\section{KESIMPULAN}

Sisik ikan gurami berpotensi sebagai agen serta teknik aplikasi lokal yang efektif dan inovatif pada perawatan periodontitis, dalam hal ini berupa gourami scale tetracycline chip. Penelitian pendahuluan ini dapat diteruskan dengan mengetahui efektivitas serapan jaringan pada tetrasiklin yang teradsorbsi pada kolagen sisik ikan.

\section{DAFTAR PUSTAKA}

1. Nagai T, Izumi M, Ishii M. Preparation and partial characterization of fish scale collagen. Int J Food Sci Tech. 2004; 39: 239-244.

2. Ikoma, Kobayashi, Tanaka, Walsh, Mann. Microstructure, mechanical, and biomimetic properties of fish scales from Pagrus major. $\mathrm{J}$ Structural Biology. 2003; 142: 327-333.

3. Huang $E$. Use of fish scales as biosorbent for the removal of copper in water. Water Res. 2007; 30: 1985-1990. 
4. Mustafiz, Rahaman, Kelly, Tango, Islam. The application of fish scales in removing heavy metals from energy-produced waste streams: the role of microbes. Energy Sources. 2003; 25(9): 905-916.

5. Buranapanitkit B. The efficacy of a hydroxyapatite composite as a biodegradable antibiotic delivery system. Clin orthop relat res. 2004; 424: 252-244.

6. Hillig W. An open-pored gelatine/hidroxyapatite composite as a potential bone substitute. $\mathrm{J}$ Mater sci mater med. 2008; 19: 7-11.

7. Budiatin AS. Biocompatible composite as gentamicin delivery system for osteomyelitis and bone regeneration. Int $\mathrm{J}$ Phar Pharmaceutical Sci. 2014; 6(3).

8. Vanderkerckhove BNA, Quirynen M, Van SD. The use of tetracycline-containing controlledrelease fibers in the treatment of refractory periodontitis. J Periodontol. 1997; 68: 353-61.

9. Horbylon GS, Martins, Guerra, Magalhaes, Machado de Menezes, Ruggiero. In vitro study of the desorption kinetic of doxycycline and tetracycline incorporated into collagen controlled released device (CRDs). African J Pharmacy Pharmacol. 2013; 7(28): 19501956.
10. Carranza FA, Newman MG, Takei HH, Klokkevold PR. Carranza's clinical periodontology 11th edition. Philadelpia: Elsevier Inc. 2006.

11. Ditjen POM. Farmakope Indonesia. Edisi Ketiga. Jakarta: Departemen Kesehatan RI. 1979.

12. Singh, Shreehari, Garg, Singh. Clinical efficacy of $\mathrm{CHX}$ chips and TC fibers as an adjunct to non surgical periodontal therapy. Eur J General Dent. 2014; 3(2): 137-139.

13. Kadam, Ganachari, Kumar, Gurunath. Drug induced tooth discolouration. Internet J Dent Sci. 2008; 7(2)

14. Good ML, Hussey DL. Minocycline: Stain Devil?. Br J Dermatol. 2003; 149: 237-239.

15. Rosen T, Hoffman TJ. Minocycline-induced discoloration of the permanent teeth. J Am Acad Dermatol. 1989; 21: 569.

16. Li RH, Wozney JM. Delivering on the promise of bone morphogenetic proteins. Trends Biotechnol. 2001; 19: 255-265. 